\title{
ANALISIS IMPLEMENTASI KURIKULUM BERBASIS KKNI DI FAKULTAS EKONOMI UNIMED
}

\author{
Eko Wahyu Nugrahadi ${ }^{1{ }^{*}}$, Indra Maipita ${ }^{2)}$, La Ane ${ }^{3)}$, Pasca Dwi Putra ${ }^{4)}$ \\ 1) Fakultas Ekonomi, Universitas Negeri Medan \\ 2) Fakultas Ekonomi, Universitas Negeri Medan \\ 3) Fakultas Ekonomi, Universitas Negeri Medan \\ 4) Fakultas Ekonomi, Universitas Negeri Medan \\ *Penulis korespondensi: ewahyunugrahadi@yahoo.com
}

\begin{abstract}
Berkaitan dengan pelaksanaan kurikulum yang tidak berjalan dengan baik dan tidak menghasilkan kompetensi lulusan sesuai dengan profil lulusan, maka maka diterbitkan Peraturan Pemerintah No. 08 Tahun 2012 dan UU Perguruan Tinggi No 12 Tahun 2012 tentang kurikulum S1 Berbasis Kerangka Kualifikasi Nasional Indonesia (KKNI) yang mengacu pada capaian pembelajaran profil lulusan. Dengan adanya KKNI diharapkan dapat perguruan tinggi dapat menghasilkan lulusan sesuai kebutuhan pasar dan dapat bersaing secara lebih luas. Penelitian ini dilakukan dengan metode diskusi kelompok (focus group discussion), angket dan studi kepustakaan. Sedangkan alat analisis yang digunakan adalah statistik deskriptif kuantitatif. Dari hasil analisis diperoleh gambaran sebagai berikut: (1) secara keseluruhan terdapat dosen pengampu mata kuliah yang tidak memberikan secara lengkap 6 (enam) jenis tugas (4.41\%) dan tugas RI merupakan jenis tugas yang banyak jumlah tidak diberikan dosen, (2) Ditinjau dari masing-masing prodi, terlihat bahwa hanya program studi Pendidikan Ekonomi dan Manajemen yang dosennya secara lengkap telah memberikan 6 (enam) jenis tugas, (3) Secara keseluruhan dosen dalam menjelaskan cara mengerjakan tugas dikategorikan pada level dipahami mahasiswa $(90,8 \%)$, demikian juga keadaannya apabila dilihat berdasarkan masing-masing prodi, (4) Secara keseluruhan sumber referensi yang diberikan dosen pada saat perkuliahan berlangsung dikategorikan relevan $(92,8 \%)$, demikian juga keadaannya apabila dilihat berdasarkan masing-masing prodi, (5) Secara keseluruhan dosen menjelaskan rubrik penilaian pada saat perkuliahan berlangsung dikategorikan pada tingkat dipahami $(83,8 \%)$, demikian juga keadaannya apabila dilihat berdasarkan masing-masing prodi, (6) Secara keseluruhan masih terdapat dosen yang belum secara jelas menetapkan waktu pengumpulan tugas, sedangkan ditinjau dari masing-masing prodi hanya dosen-dosen prodi Manajemen yang ntelah memberikan kejelasan waktu pengumpulan tugas.
\end{abstract}

Keywords: KKNI, Profil Lulusan, Perguruan Tinggi 


\section{PENDAHULUAN}

Seiring dengan perkembangan ilmu pengetahuan dan persaingan dalam dunia kerja sekarang ini, lulusan perguruan tinggi dituntut memiliki profil lulusan sesuai dengan bidang ilmu yang dimiliki. Oleh karena itu, diperlukan kurikulum yang didalamnya terdapat mata kuliah yang memberikan keahlian inti yang akan dicapai.

Sesuai dengan Peraturan Pemerintah No. 17 Tahun 2010 Pasal 97 bahwa kurikulum perguruan tinggi dikembangkan dan dilaksanakan berbasis kompetensi (KBK) yang ditegaskan oleh peraturan Kepmendiknas No. 232/U/2000 tentang Pedoman Penyusunan Kurikulum Perguruan Tinggi dan Penilaian Hasil Belajar Mahasiswa serta No. 045/U/2002 tentang Kurikulum Inti Perguruan Tinggi. Tetapi pelaksanaan kurikulum ini tidak berjalan dengan baik dan tidak menghasilkan kompetensi lulusan sesuai dengan profil lulusan. Oleh karena itu, terbitlah Peraturan Pemerintah No. 08 Tahun 2012 dan UU Perguruan Tinggi No 12 Tahun 2012 tentang kurikulum S1 Berbasis Kerangka Kualifikasi Nasional Indonesia (KKNI) yang mengacu pada capaian pembelajaran profil lulusan.

Dengan adanya KKNI diharapkan dapat perguruan tinggi dapat menghasilkan lulusan sesuai kebutuhan pasar dan dapat bersaing secara lebih luas. Dalam KKNI terdapat Sembilan level kualifikasi akademik SDM Indonesia yang dimulai dari level 1 yaitu pendidikan dasar sampai dengan level 9 (strata 3/ S-3). Adapun level kualifikasi dapat dilihat pada Gambar 1.

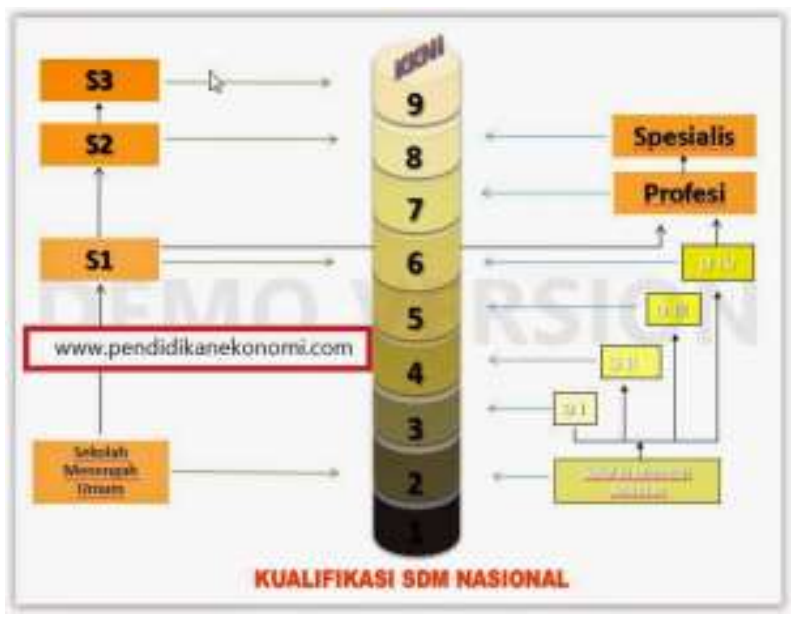

Gambar 1 Kualifikasi Akademik SDM Indonesia

Oleh karena itu, perlu kiranya pengembangan kurikulum yang dilakukan oleh Universitas Negeri Medan dalam menyempurnakan pendidikan dan peningkatan
NIAGAWAN Vol 7 No 1 Maret 2018

ketrampilan lulusan dalam memenuhi persaingan dunia kerja sekarang ini. Fakultas Ekonomi Unimed mulai mengembangkan kurikulum berbasis KKNI tahun 2014 dengan menyiapkan mata kuliah inti untuk pencapaian lulusan yang diharapkan. Adapun penetapan capaian lulusan disesuaikan dengan visi dan misi universitas dan fakultas. Pada tahun 2014, dihasilkan suatu kurikulum KBK berbasis KKNI yang memiliki keterbatasan pada penetapan profil lulusan, learning outcome, bahan kajian dan mata kuliah. Pelaksanaan kurikulum berbasis KKNI secara murni dilaksanakan pada tahun 2016 pada semester ganjil 2016-2017.

Disamping itu, lulusan dari kurikulum ini harus merujuk pada standar nasional yang disesuaikan dengan tridharma perguruan tinggi yaitu pendidikan, penelitian dan pengabdian kepada masyarakat. Oleh karena itu, mata kuliah yang terdapat di FE Unimed ini harus didalamnya unsur pengajaran, penelitian, dan pengabdian kepada masyarakat.

FE Unimed mulai melaksanakan kurikulum berbasis KKNI ini pada tahun ajaran Ganjil 2016/2017 dimana dalam pelaksanaan kurikulum ini terdapat enam tugas wajib yang harus dilaksanakan mahasiswa. Adapun tugas wajib ini terdiri dari tugas rutin, critical journal review, critical book report, rekaya ide, mini riset, project dimana ke enam tugas itu wajib dilaksanakan mahasiswa dalam pencapaian tujuan dari mata kuliah sesuai dengan kurikulum berbasis KKNI. Setiap mata kuliah yang diampu mahasiswa, wajib melaksanakan enam tugas.

Sekarang ini, FE Unimed telah melaksanakan kurikulum KKNI dua semester yaitu semester ganjil dan genap TA 2016/2017. Dalam pelaksanaannya masih terdapat beberapa kendala seperti pelaksanaan enam tugas yang dilaksanakan pada setiap mata kuliah, format penilaian enam tugas, pemahaman mahasiswa dalam pelaksanaan tugas serta kendala lainnya. Oleh karena itu, perlu diketahui sejauh mana efektivitas pelaksanaan kurikulum KKNI di FE Unimed ini sehingga kedepan dapat dilakukan penyempurnaan pelaksanaannya.

\section{TINJAUAN PUSTAKA \\ Kurikulum KKNI}

Adanya perkembangan kurikulum di Perguruan Tinggi sekarang ini bertujuan untuk meningkatkan mutu lulusan sehingga dapat mengikuti perkembangan zaman dan dapat bersaing dalam dunia kerja. Perkembangan 
IPTEK sekarang ini mengharuskan perguruan tinggi dapat memperbaharui keilmuan serta kompetensi lulusan sehingga dapat memenuhi sesuai kebutuhan pasar. Disamping itu, adanya Masyarakat Ekonomi ASEAN (MEA) sekarang ini mengharuskan perguruan terus aktif dan menyiapkan lulusan untuk dapat bersaing dengan tenaga kerja yang berasal dari luar negeri.

Salah satu usahanya yaitu dengan melakukan perubahan atau pembaharuan terhadap kurikulum pada perguruan tinggi. Dimana pada kurikulum yang lama tidak mencakapi kompetensi capaian dan profil lulusan. Oleh karena itu, sekarang ini perguruan tinggi dituntut untuk dapat membuat profil lulusan sehingga akan tampak lulusan dari masing-masing program studi di perguruan tinggi tersebut akan dicapai. Oleh karena itu, salah satunya dengan pelaksanaan kurikulum KKNI dalam setiap mata kuliah yang diajarkan pada perguruan tinggi.

Hal ini terkait dengan Peraturan Pemerintah No. 17 Tahun 2010 Pasal 97 menyatakan bahwa kurikulum perguruan tinggi dikembangkan dan dilaksanakan berbasis kompetensi (KBK). Pernyataan ini telah menegaskan kembali Kepmendiknas No. 232/U/2000 tentang Pedoman Penyusunan Kurikulum Pendidikan Tinggi dan Penilaian Hasil Belajar Mahasiswa, serta No. 045/U/2002 tentang Kurikulum Inti Pendidikan Tinggi.

Dalam upaya melakukan kualifikasi terhadap lulusan perguruan tinggi di Indonesia, pemerintah telah menerbitkan Perpres No. 08 tahun 2012 tentang Kerangka Kualifikasi Nasional Indonesia (KKNI) dan Lampirannya yang menjadi acuan dalam penyusunan capaian pembelajaran lulusan dari setiap jenjang pendidikan secara nasional, juknis Perpres ini Permendikbud no. 73 Tahun 2013.

Terbitnya Perpres No. 08 tahun 2012 dan UU PT No. 12 Tahun 2012 Pasal 29 ayat (1), (2), dan (3) telah berdampak pada kurikulum dan pengelolaannya di setiap program. Kurikulum yang pada awalnya mengacu pada pencapaian kompetensi menjadi mengacu pada capaian pembelajaran (learning outcomes). Secara ringkas KKNI terdiri dari Sembilan level kualifikasi akademik SDM Indonesia.

Dengan adanya KKNI ini diharapkan akan mengubah cara melihat kompetensi seseorang, tidak lagi semata Ijazah tapi dengan melihat kepada kerangka kualifikasi yang
NIAGAWAN Vol 7 No 1 Maret 2018

disepakati secara nasional sebagai dasar pengakuan terhadap hasil pendidikan seseorang secara luas (formal, non-formal, atau in formal) yang akuntanbel dan transparan.

Pelaksanaan KKNI melalui 8 tahapan yaitu melalui penetapan Profil Kelulusan, Merumuskan Learning Outcomes, Merumuskan Kompetensi Bahan Kajian, Pemetaan LO Bahan Kajian, Pengemasan Matakuliah, Penyusunan Kerangka kurikulum, Penyusuan Rencana Perkuliahan.

Untuk meningkatkan kualitas lulusan perguruaan tinggi. Rambu-rambu yang harus dipenuhi di tiap jenjang perlu dapat membedakan:

1. Learning Outcomes

2. Jumlah sks

3. Waktu studi minimum

4. Mata Kuliah Wajib: untuk mencapai hasil pembelajaran dengan kompetensi umum

5. Proses pembelajaran yang berpusat pada mahasiswa

6. Akuntabilitas asesmen

7. Perlunya Diploma Supplement (surat keterangan pelengkap ijazah dan transkrip)

\section{METODE PENELITIAN}

Lokasi dan waktu Penelitian

Penelitian ini dilaksanakan di Fakultas Ekonomi Unimed pada satuan kerja tingkat program studi. Waktu penelitian ini direncanakan selama 3 (tiga) bulan dimulai pada bulan Juli s.d September 2017.

\section{Populasi dan Sampel}

Populasi pada penelitian ini adalah seluruh mahasiswa semester 1 tahun akademik 2017-2018 dan semester 3 tahun akademik 2016-2017.

Adapun sampel yang digunakan adalah Stratified Random Sampling dengan teknik Tabel Random.

\section{Metode Pengumpulan Data Penelitian}

Penelitian ini menggunakan beberapa teknik atau alat pengumpulan data, sebagai pendukung dalam proses pencarian dan penggalian data penelitian. Metode pengumpulan data dalam penelitian ini menggunakan cara yakni diskusi kelompok (focus group discussion), angket dan studi kepustakaan. 


\section{Analisis Data}

Data yang terkumpul dianalisis secara deskriptif dengan menggunakan tabel dan persentase. Teknik analisis data dalam penelitian ini dilakukan dengan beberapa tahapan yaitu:

1. Tahap pertama seluruh data ditabulasi dan kemudian dianalisis dengan pendekatan statistik deskriptif yaitu melihat dari nilai mean, median, modus dan kumulatif data yang diperoleh baik secara jumlah absolut maupun tingkat persentase. Data yang dihitung dengan pendekatan statistik deskriptif diolah dengan bantuan software statistik SPSS versi 21, dan kemudian disajikan juga dalam bentuk grafik

2. Tahap kedua seluruh data yang telah disajikan dalam bentuk grafik, dibahas oleh Tim peneliti untuk dibuatkan justifikasi penjelasan data guna pengambilan kesimpulan penelitian

3. Setelah adanya pembahasan dan justifikasi dari Tim peneliti, maka pada Tahap ketiga hasil penelitian di bahas lebih mendalam dengan para pihak yang relevan dalam sebuah forum diskusi terfokus (Focus Group Discussion) guna mendapatkan masukan penyempurnaan hasil penelitian.

Sedangkan alat analisis yang digunakan untuk menjawab permasalahan yang diajukan dalam penelitian ini adalah statistik deskriptif kuantitatif

\section{HASIL DAN PEMBAHASAN \\ Hasil Penelitian}

Implementasi kurikulum berbasis KKNI yang dilaksanakan di Universitas Negeri Medan khususnya Fakultas Ekonomi memberikan dampak terhadap luaran dari lulusan mahasiswa. Fakultas Ekonomi Unimed mulai melaksanakan kurikulum berbasis KKNI pada Tahun Ajaran Ganjil 2017/2018 dengan metode pembelajaran student learning center yang mewajibakan 6 tugas yang terdiri dari dari tugas rutin, critical journal review, critical book report, rekaya ide, mini riset, project, dimana ke enam tugas itu wajib dilaksanakan mahasiswa dalam pencapaian tujuan dari mata kuliah sesuai dengan kurikulum berbasis KKNI.

Penelitian ini bertujuan melihat keefektifan dari kurikulum berbasis KKNI yang dilaksanakn di Fakultas Ekonomi Unimed. Adapun instrumen yang digunakan adalah kuisioner yang dibagikan terhadap mahasiswa dan dosen. Metode analisis data menggunakan
NIAGAWAN Vol 7 No 1 Maret 2018

statistik deskriptif yang menggambarkan jawaban atas pertanyaan yang disampaikan kepada objek penelitian. Adapun hasil dari kuisioner dapat dilihat pada uraian di bawah ini.

\section{Pembahasan Penelitian}

Dari hasil penelitian diatas dapat dijelaskan bahwa pelaksanaan kurikulum 2016 berbasis KKNI memberikan manfaat yang besar bagi dosen dan mahasiswa khususnya dalam memberikan ketrampilan dan membentuk karakter dan sifat yang baik. Pemberian tugas pada mahasiswa memberikan dampak positif kedepan seperti melatih kedisiplinan, membuat mahasiswa menjadi lebih tanggap dan cepat mengambil keputusan serta tepat waktu dalam menyelesaikan setiap tugas. Penelitian ini untuk mengetahui dampak pemberian 6 tugas wajib bagi mahasiswa yang masuk pada tahun ajaran 2016-2017 sampai dengan sekarang. Hasil penelitian ini menunjukkan bahwa keseluruhan program studi pada fakultas ekonomi memberikan 6 tugas wajib di Fakultas Ekonomi Unimed yaitu tugas rutin, critical book report, critical journal review, rekayasa ide, mini riset, dan project dengan menyampaikan format dan cara mengerjakan serta rubric penilaian yang akan dilakukan. Tujuannya memberikan transparansi kepada mahasiswa mengenai proses dalam menyelesaikan tugas yang diberikan. Disamping itu, adanya jadwal waktu pengumpulan tugas memberikan manfaat kedisiplinan bagi mahasiswa agar mengumpulkan tepat waktu. Dalam menyelesaikan tugas tersebut, dosen juga memberikan sumber belajar yang relevan dalam menyelesaikan tugas yang akan diselesaikan sehingga memberikan bantuan kepada mahasiswa dalam menyelesaikannya.

Disamping itu, dilihat tingkat pemahamannya mahasiswa memiliki pemahaman baik mengenai penyelesaian tugas tersebut seperti cara mengerjakan, format penulisan, rubric penilaian, jadwal pengumpulan sehingga mahasiswa akan dapat lebih fokus menyelesaikan tugas tersebut tanpa menimbulkan ketidaktahuan mengenai proses penyelesaian. Seperti kita ketahui bahwa mahasiswa tersebut belum memperoleh mata kuliah metodologi penelitian dan statistik sehingga dengan adanya penjelasan dari dosen dalam menyelesaikan tugas tersebut akan memberikan gambaran dalam penyelesaian tugas 
yang pada akhirnya mahasiswa akan merasa puas atas tugas yang diberikan.

Dari hasil rekapitulasi kuisioner mengenai hasil penilaian tugas menunjukkan bahwa dosen menjelaskan bobot nilai tugas yang dilaksanakan agar mencapai kelulusan yang tujuannya akan memberikan motivasi kepada mahasiswa dalam menyelesaikan tugasnya dengan baik dan berkualitas. Hasilnya juga tugas yang diselesaikan mencapai kualitas yang baik sehingga dengan adanya penjelasan tersebut memberikan dampak yang baik bagi mahasiswa. Disamping itu, pentingnya dikembalikan tugas yang telah diberikan akan memberikan gambaran dan intropeksi kedepan untuk memperbaiki tugas menjadi lebih baik. Selama ini jika kita lihat masih banyak dosen yang tidak mengembalikan tugas yang telah diselesaikan oleh mahasiswa. Hal ini akan berdampak negatif terhadap perbaikan dan semangat mahasiswa dimana mahasiswa tidak akan mengetahui kekurangan dari tugas yang telah diselesaikan. Jika kita lihat dari hasil kuisioner menunjukkan bahwa tidaklah semua dosen mengembalikan tugas wajib yang dikerjakan mahasiswa. Oleh karena itu, perlunya pengembalian tugas akan memberikan dampak yang besar terhadap kualitas tugas kedepan.

Pada akhirnya, adanya 6 tugas wajib juga memberikan manfaat bagi mahasiswa seperti dengan meningkatkan kompetensi mahasiswa dimana mahasiswa akan lebih tertantang dalam menghadapi kompetensi kedepan yang pada akhirnya akan dapat bersaing pada dunia pekerjaan. Manfaat berikutnya yaitu pengembangan karakter dimana akan tumbuhnya karakter yang baik dan tidak mudah menyerah dalam diri mahasiswa. Manfaat lainnya yaitu adanya kerjasama dimana dengan adanya tugas wajib yang diselesaikan secara bersama akan menunjukkan kerjasama tim yang kuat dalam menyelesaikan suatu permasalahan.

Selain itu, dengan mengerjakan 6 tugas ini akan memberikan gambaran dan keterbukaan pikiran dari mahasiswa mengenai pengaplikasikan dalam perkembangan IPTEK. Hal ini bertujuan dalam menyelesaikan permasalahan yang akan dihadapi sehingga pada akhirnya ide tersebut dapat mendorng mahasiswa dalam menyusun proposal PKM yang dapat dipertandingkan baik tingkat nasional maupun internasional. Dalam menyusun proposal PKM ini perlu adanya kreativitas mahasiswa dalam menghasilkan suatu produk ataupun IPTEK. Sehingga dengan adanya 6 tugas wajib ini akan meningkatkan kreativitas mahasiswa dalam menghasilkan produk maupun IPTEK.

Dalam menyelesaikan tugas tersebut, ada beberapa tugas yang sebelumnya harus dipresentasikan didepan kelas. Tujuannya agar melatih mahasiswa agar tidak gugup dan terbiasa untuk berkomunikasi didepan publik. Oleh karena itu, dengan adanya pemaparan tugas wajib itu akan memberikan dampak terhadap peningkatan etika dalam berkomunikasi mahasiswa didepan publik. Penyelesaian tugas juga harus dilakukan secara jujur dengan tidak melakukan plagiatrisme sehingga pentingnya kejujuran ilmiah didalam tugas tersebut. Hasil penelitian ini menunjukkan bahwa rata-rata mahasiswa mempunyai tingkat kejujuran ilmiah yang tinggi. hal ini menunjukkan bahwa mahasiswa jujur secara ilmiah dalam menyelesaikan tugas dikarenakan mereka memiliki tanggung jawab baik bagi diri mereka sendiri maupun institusi.

Manfaat lain yang dirasakan mahasiswa dari menyelesaikan 6 tugas ini adalah adanya keperdulian dan kedisiplinan dalam mengikuti perkuliahan. Hasil peneltian ini menunjukkan adanya keperdulian dan kedisiplinan yang tinggi dari dalam diri mahasiswa dikarenakan rasa tanggung jawab yang pegang. Mahasiswa merasa jika tidak mengikuti perkuliahan akan ketinggalan untuk memperoleh pengetahuan. Sehingga pada akhirnya akan menculnya kemandirian dan inisiatif dalam diri mereka. Sehingga dapat disimpulkan bahwa 6 tugas wajib dalam kurikulum 2016 berbasis KKNI akan berdampak positif disamping memberikan manfaat yang besar bagi mahasiswa.

\section{KESIMPULAN DAN SARAN \\ Kesimpulan}

Berdasarkan hasil dan pembahasan dapat disimpulkan sebagai berikut:

1. Secara keseluruhan terdapat dosen pengampu mata kuliah yang tidak memberikan secara lengkap 6 (enam) jenis tugas $(4.41 \%)$ dan tugas RI merupakan jenis tugas yang banyak jumlah tidak diberikan dosen

2. Ditinjau dari masing-masing prodi, terlihat bahwa hanya program studi Pendidikan Ekonomi dan Manajemen yang dosennya secara lengkap telah memberikan 6 (enam) jenis tugas 
3. Secara keseluruhan dosen dalam menjelaskan cara mengerjakan tugas dikategorikan pada level dipahami mahasiswa $(90,8 \%)$, demikian juga keadaannya apabila dilihat berdasarkan masing-masing prodi

4. Secara keseluruhan sumber referensi yang diberikan dosen pada saat perkuliahan berlangsung dikategorikan relevan $(92,8 \%)$, demikian juga keadaannya apabila dilihat berdasarkan masing-masing prodi

5. Secara keseluruhan dosen menjelaskan rubrik penilaian pada saat perkuliahan berlangsung dikategorikan pada tingkat dipahami $(83,8 \%)$, demikian juga keadaannya apabila dilihat berdasarkan masing-masing prodi

6. Secara keseluruhan masih terdapat dosen yang belum secara jelas menetapkan waktu pengumpulan tugas, sedangkan ditinjau dari masing-masing prodi hanya dosen-dosen prodi Manajemen yang telah memberikan kejelasan waktu pengumpulan tugas.

\section{Saran}

disarankan sebagai berikut:

Berdasarkan kesimpulan dapat

1. Merevitalisasi standar penilaian dari keenam jenis tugas

2. Melakukan review terhadap pedoman/panduan penerapan jenis 6 (enam) tugas

3. Mengadakan workshop atau FGD kepada seluruh dosen FE guna peningkatan pemahaman dosen dalam penerapan 6 (enam) jenis tugas.

\section{REFERENSI}

Anih, Euis. 2015. Manajemen Implementasi Kebijakan Pengembangan Kurikulum Di Perguruan Tinggi Berbasis Kompetensi. Jurnal Pendidikan Unsika (JUDIKA), Vol 3:1 (1-21).

Finch, Curtis \& Crunkilton, J. R. (1979). Curriculum Development In Vocational Technical Education. New York: Allyn and Bacon

Hasbullah. (2006). Otonomi Pendidikan. Jakarta: PT.Grafindo

Keputusan Menteri Pendidikan dan Kebudayaan Republik Indonesi Nomor 56/U/1994 Tentang Kurikulum

Keputusan Menteri Pendidikan Nasional Republik Indonesia Nomor 045/U/2002 Tentang Kurikulum Inti Pendidikan Tinggi
NIAGAWAN Vol 7 No 1 Maret 2018

Keputusan menteri Pendidikan Nasional Republik Indonesia Nomor 232/U/2000 Tentang Pedoman Penyusunan Kurikulum Pendidikan Tinggi dan Penilaian Hasil Belajar Mahasiswa

McAshan, H.H. (1981). Competency Based Education and Behavioral Objectives. USA: Educational Technology Publication.

Mulyasa, E. (2004). Implementasi Kurikulum 2004; Panduan Pembelajaran KBK. Bandung: P.T. Remaja Rosdakarya.

Mulyasa, E.. (2003). Kurikulum Berbasis Kompetensi. Konsep; Karakteristik dan Implementasi. Bandung: P.T. Remaja Rosdakarya.

Oliva, F.P. (1976). Developing the Curriculum. USA: Harper Collin Publisher.

Peraturan Pemerintah Republik Indonesia Nomor 17 Tahun $2010 \quad$ Tentang Pengelolaan dan Penyelenggaraan Pendidikan.

Peraturan Pemerintah Republik Indonesia Nomor 30 Tahun 1990 Tentang Pendidikan Tinggi

Peraturan Pemerintah Republik Indonesia Nomor 60 Tahun 1999 Tentang Pendidikan Tinggi

Peraturan Presiden Republik Indonesia Nomor 8 Tahun 2012 Tentang Kerangka Kualifikasi Nasional Indonesia

PP Nomor: 60 \& 61 Tentang Pendidikan Tinggi dan Perguruan Tinggi, Tahun 1999.

Republik Indonesia. (2003). Undang-Undang Sistem Pendidikan Nasional. Bandung: Citra Umbara

Republik Indonesia. (2006). Undang-Undang Guru dan Dosen dan Undang-Undang Sistem Pendidikan Nasional. Wacana Intelektual.

Sugiyono. (2010). MetodePenelitian Kuantitatif Kualitatif \& RND. Bandung: Alfabeta

Sukmadinata, N.S. (2005). Metode Penelitian Pendidikan. Bandung: PT Remaja Rosdakarya.

Sutikno, S. (2004). Kurikulum dan Pembelajaran Kompetensi. Bandung: Kesuma Karya.

Sutikno, S. (2012). Manajemen Pendidikan Langkah Praktis Mewujudkan Lembaga Pendidikan Yang Unggul. Lombok: Holistica.

Undang-Undang Republik Indonesia Nomor 20 Tahun 2003 Tentang Sistem Pendidikan Nasional. 